\title{
SYSTEMATIC LITERATURE REVIEW: DETERMINATION OF GOVERNMENT POLICY IN HEALTH AND EDUCATION DEVELOPMENT FOR IMPROVED HUMAN CAPITAL
}

\author{
Rizki Afri Mulia', Nika Saputra ${ }^{2}$ \\ Department of Public Administration, STISIP Imam Bonjol, Padang \\ Master of Public Administration, Padang State University, Indonesia \\ Email: rizki.afri.mulia@stisipimambonjol.ac.id
}

\begin{abstract}
Human capital plays a very strategic role in supporting the competitiveness of a country or region. This study aims to determine how the development of human capital is seen from the theoretical and practical settings and how the solutions are resolved. With the approach pattern, Systematic Literature Review in the journal already is published from the year 2011 until 2021 it got the result that human capital research is currently focused on two topics and trends: the development of education and health. The method often used in human capital research is a quantitative approach of $62 \%$, a qualitative approach of $36 \%$ and a mixed-method approach of $2 \%$. The cause of the low increase in human capital is the lack of government attention in improving education and health. The solution given to answer the problem of low human capital is by improving the quality of education and improving public health facilities to achieve better human capital. To achieve this goal, the government plays an important role in this increase.
\end{abstract}

Keywords: Systematics Literature Review, Government Policy, Education, Health, Human capital.

\section{INTRODUCTION}

Human capital is a term often used by economists for education, health, and other human resources, which if enhanced capabilities can increase productivity. If education is believed to increase the value and quality of human capital, then the formation of human capital is an important means of encouraging economic growth. Therefore, if education is only considered a signal of the quality of a person's education, it is believed that the education received by workers will not increase their productivity. (Fahmi \& Mulyono, 2016). From a health perspective, a prosperous country is one of the indicators reflected in a healthy society. A prosperous society is built from several aspects of life, namely the fulfilment of food, housing, security and health needs (Artana, 2016).

On the other hand, it is difficult to identify and measure human resources directly. Research is usually done indirectly. Therefore, a more accurate measurement of human resources must be complemented by more meaningful indicators. However, the concept of human capital has been extended to human resource development related to a healthy lifestyle, knowledge and standard of living. (Adriani, 2019).

Human resource development also affects public health by reducing fetal and infant mortality rates and increasing children's health and life expectancy. Many studies conducted 
in South Korea, Taiwan, Japan, China and several other countries have confirmed this. Literacy can help people choose and buy the right food and medicine, as well as better access to public health services (Tobing, 2011).

National Education and health is a fundamental goal of development. Health is wellbeing, and education is essential for achieving a fulfilling and rewarding life, and both are essential for shaping the capacities of more people, which are at the heart of what development means.

Indonesia's score in the Human Capital Index in 2018 is 0.53 . This means that, on average, an Indonesian worker in future generations will only have the productivity of 53\% of its full potential if he/she completes education \& has full access to health. Even though Indonesian children today can usually complete 12.3 years of education at the age of 18 , they can only receive an average of 7.9 years of education due to the low quality of education. Also, nearly a third of Indonesian children are stunted, which means they are at risk of experiencing physical and cognitive limitations.

The data collected is a journal that discusses the development of health and education to increase human capital from 2011 to 2021. These data are identified using the Systematic Literature Review (SLR) method. By using the Systematic Literature Review method, journals can be systematically reviewed and identified, each of which follows a predetermined step or protocol. Also, the Systematic Literature Review method can avoid subjective recognition, and it is hoped that the results of this introduction can be added to the literature on the use of the Systematic Literature Review method in the introduction of journals.

\section{LITERATURE REVIEW}

\section{Human Capital}

Todaro \& Smith (2006) distinguishes the concept between human capital and human resources. Human capital is a resource of skills, skills, ideas, health, etc. This is the result of spending or spending on education, provision and development of vocational training programs, medical care and maintenance programs. Meanwhile, human resources are the quantity and quality of a country's workforce. Human capital can be defined in various ways, but in general human capital means knowledge, skills, abilities, and other human characteristics related to economic activity (OECD 1998). Therefore, human capital must be treated as a factor of production that is equal to physical capital and separated from labour. 
Then, based on Adam Smith's statement, he stated that humans are the main factor that determines the prosperity of the nations. The reason is that nature (land) has no meaning if there are no skilled human resources to cultivate it so that it is useful. In other words, human capital is one of the determining factors in increasing economic growth. Without quality human capital, physical capital will be meaningless. According to Kumar (2006), human capital is closely related to the skills and knowledge contained in humans obtained through training and experience education which will be useful in the production of goods, services and further development of knowledge. Therefore, the main key to human capital is that education is complemented by other factors including health, work environment, and other.

\section{Systematic Literature Review}

Systematic Literature Review is a term used to refer to a particular research or research methodology and development carried out to collect and evaluate research related to a particular focus topic.

Systematic Literature Review research is carried out for various purposes, including to identify, review, evaluate, and interpret all available research on the topic area of the phenomenon of interest, with certain relevant research questions. Systematic Literature Review is also often required for determining the research agenda, as part of a dissertation or thesis, as well as a complementary part of a research grant application.

\section{RESEARCH METHODOLOGY}

\section{Metode Review}

A systematic approach to review the literature on Health and Education Development for Human Capital Improvement. Systematic Literature Review (SLR) is now a well-established review method in Human capital. Systematic Literature Review aims at the process of finding, assessing, and interpreting all available evidence to provide answers to specific study questions. (Kitchenham \& Charters, 2007). This literature review has been conducted as a Systematic Literature Review based on the original guidelines proposed by Kitchenham \& Charters (2007). The review method, style, and several figures in this section are also motivated by (Unterkalmsteiner et al., 2011) and (Radjenović et al., 2013).

As shown in Figure 1, the Systematic Literature Review is carried out in three stages: planning, implementing and reporting the literature review. In the first step requirements for a systematic review are identified (Step 1). The purpose of conducting a 
literature review is discussed in the introduction to this chapter. Then, existing systematic reviews on Human capital development are identified and reviewed. The review protocol was designed to guide the conduct of the review and reduce the possibility of researcher bias (Step 2). It defines the research question, the search strategy, the study selection process by inclusion and exclusion criteria, the quality assessment, and finally the data extraction and synthesis process. Review protocols are presented, developed, evaluated and improved regularly during the implementation and reporting stages of the review.

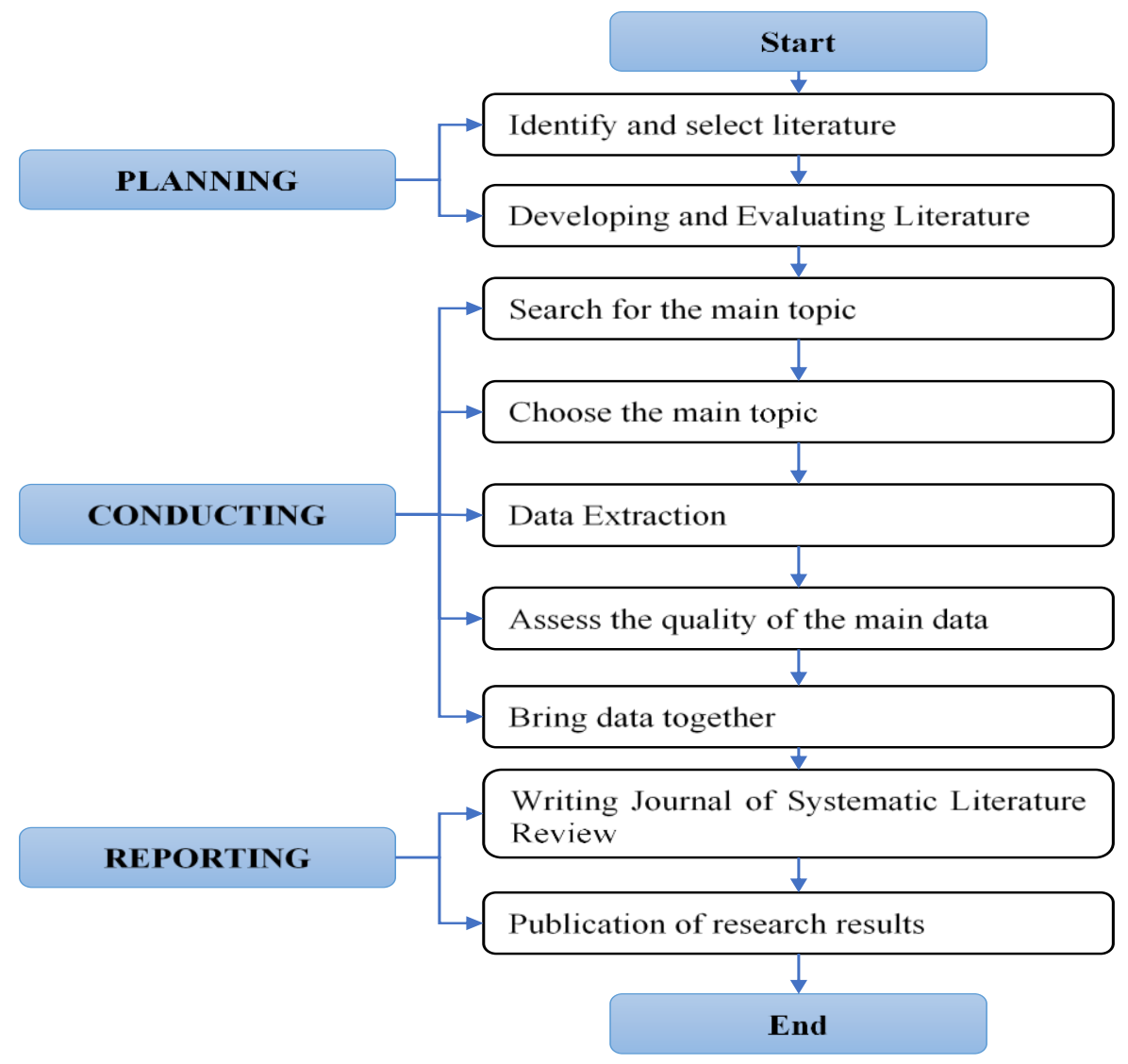

Figure 1. Steps for a Systematic Literature Review

\section{Research Question}

The research question was designed to keep the systematic reviews carried out in focus. Research questions are prepared with the help of the criteria for Population, Intervention, Comparison, Outcomes, and Context abbreviated as PICOC (Kitchenham \& Charters, 2007). Table 1. shows the PICOC structure of the research questions on Systematic Literature Review: Health and Education Development for Human Capital Improvement. 
Table 1. Summary of PICOC Human capital development

\begin{tabular}{ll}
\hline Population & Human capital, education, health \\
\hline Intervention & $\begin{array}{l}\text { The low level of education, the level of health is not good, the low level } \\
\text { of human capital }\end{array}$ \\
\hline Comparison & $\mathrm{n} / \mathrm{a}$ \\
\hline Outcomes & $\begin{array}{l}\text { Increasing Health and Education Development in increasing human } \\
\text { capital }\end{array}$ \\
\hline Context & $\begin{array}{l}\text { Collaboration between academics, policymakers and government } \\
\text { institutions. }\end{array}$ \\
\hline
\end{tabular}

The research question that was built in this study is as shown in table 2. below:

Table 2. Research Questions in Literature Review

\begin{tabular}{|c|c|c|}
\hline ID & Research Question & Motivation \\
\hline RQ1 & $\begin{array}{l}\text { Which journal is the most significant journal } \\
\text { of Health and Education Development for } \\
\text { Human Capital Improvement? }\end{array}$ & $\begin{array}{l}\text { Identification of the most } \\
\text { significant journals in the field of } \\
\text { Health and Education Development } \\
\text { for Human Capital Improvement }\end{array}$ \\
\hline RQ2 & $\begin{array}{l}\text { Who are the most active and influential } \\
\text { researchers in Health and Education } \\
\text { Development for the Improvement of human } \\
\text { capital? }\end{array}$ & $\begin{array}{l}\text { Identification of the most active } \\
\text { and influential researchers in } \\
\text { Health and Education Development } \\
\text { for the Improvement of human } \\
\text { capital }\end{array}$ \\
\hline RQ3 & $\begin{array}{l}\text { What are the research topics and trends were } \\
\text { chosen by the researchers on Health and } \\
\text { Education Development for Human Capital } \\
\text { Improvement? }\end{array}$ & $\begin{array}{l}\text { Identification of research topics and } \\
\text { trends selected by researchers on } \\
\text { Health and Education Development } \\
\text { for Human Capital Improvement }\end{array}$ \\
\hline RQ4 & $\begin{array}{l}\text { What types of methods are most often used } \\
\text { in research on Health and Education } \\
\text { Development for Human Capital } \\
\text { Improvement? }\end{array}$ & $\begin{array}{l}\text { Identify the types of methods most } \\
\text { often used in research on Health } \\
\text { and Education Development for } \\
\text { Human Capital Improvement }\end{array}$ \\
\hline RQ5 & $\begin{array}{l}\text { What methods are the best performing when } \\
\text { used for Health and Education Development } \\
\text { for Improvement of human capital? }\end{array}$ & $\begin{array}{l}\text { Identify the best-performing } \\
\text { methods when used for Health and } \\
\text { Education Development for Human } \\
\text { Capital Improvement }\end{array}$ \\
\hline RQ6 & $\begin{array}{l}\text { What methods are proposed for Health and } \\
\text { Education Development for Improvement of } \\
\text { human capital? }\end{array}$ & $\begin{array}{l}\text { Identification of the proposed } \\
\text { method for Health and Education } \\
\text { Development for Improvement of } \\
\text { human capital }\end{array}$ \\
\hline RQ7 & $\begin{array}{l}\text { What kind of framework is proposed for } \\
\text { Health and Education Development for } \\
\text { Improvement of human capital? }\end{array}$ & $\begin{array}{l}\text { Identify the most frequently used } \\
\text { frameworks for Health and } \\
\text { Education Development for the } \\
\text { Improvement of human capital }\end{array}$ \\
\hline
\end{tabular}

From table 2. above, the method of predicting weaknesses in increasing human capital is to answer questions on RQ4 to RQ7. Then determine what is significant and what 
is not. RQ4 to RQ7 are the main questions in this study, while other questions, namely RQ1 to RQ3, are used to assist in evaluating the context of the research.

Figure 2 shows a basic mind map from a systematic literature review. The main objective of this systematic literature review is to identify methods for human capital enhancement, frameworks and data sets used in human capital enhancement.

Figure 2. Mind Map

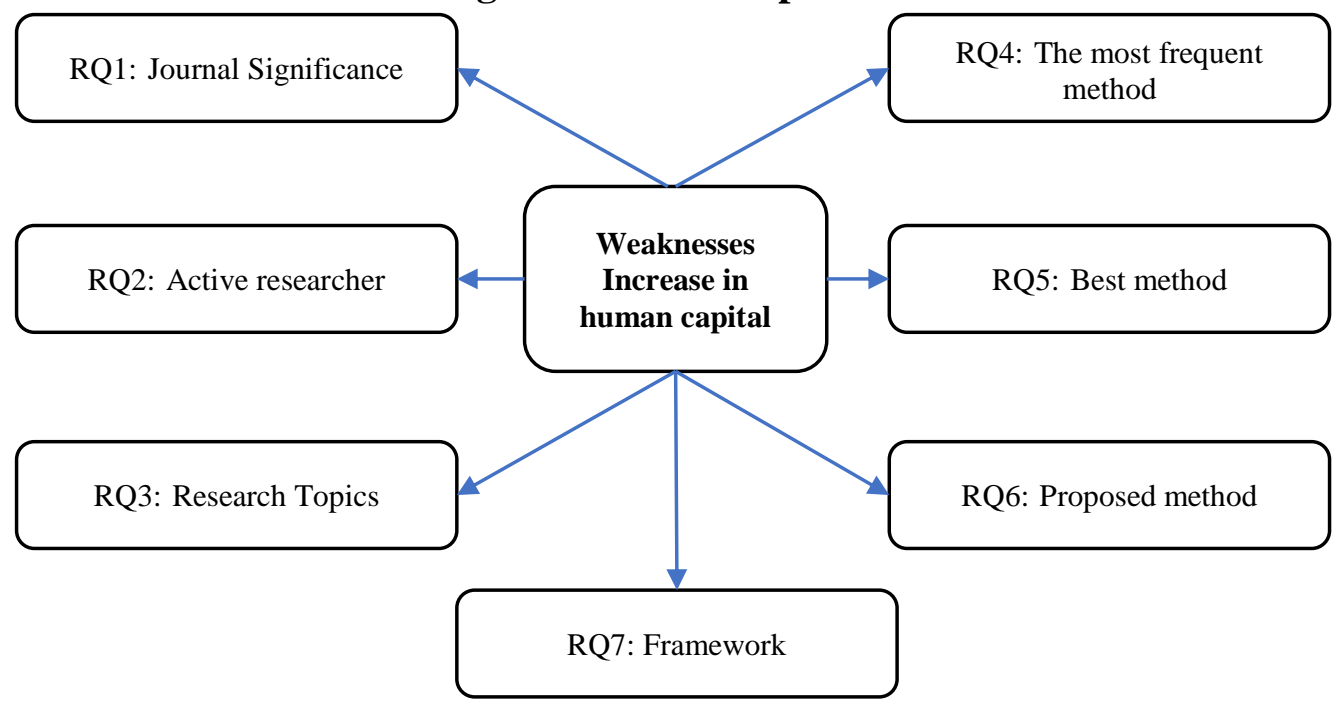

\section{Search Strategy}

The strategy or search process in the Systematic Literature Review (SLR) that is carried out consists of several activities, namely selecting digital libraries, defining search strings, carrying out searches, refining the search strings and retrieving the initial list of main studies from digital libraries that match the search strings. Before starting a search, a suitable set of databases should be selected to increase the likelihood of finding highly relevant articles. The most popular literature databases in the field were searched to have the widest possible set of studies. A broad perspective is required for broad literature coverage.

The search string is developed according to the following steps:

1. Identify the search terms from PICOC, especially from Population and Intervention

2. Identify the search term of the research question

3. Identify search terms in titles, abstracts and relevant keywords

4. Identify synonyms, alternative spellings, and antonyms of the search term

5. Advanced search string construction using identified search terms, and Boolean and OR

In the search process, the search data must be adjusted to the storage process, because adjusting the search data will increase the list of irrelevant studies. The search data is then adjusted to meet the specific requirements of each database. The database is 
searchable by title, keywords, and abstracts. Searches are limited by the year of publication: that is, the last 10 years of the writing of this study. Two types of publication namely journal papers and conference proceedings are included.

\section{Study Selection}

Inclusion and exclusion criteria were used to select primary studies. These criteria are shown in Table 3.

\section{Table 3 Inclusion and Exclusion}

\begin{tabular}{|c|c|}
\hline $\begin{array}{l}\text { Inclusion } \\
\text { Criteria }\end{array}$ & $\begin{array}{l}\text { 1. Studies in academics and institutions use large and small scale data } \\
\text { sets } \\
\text { 2. Studies that discuss and compare the development of health and } \\
\text { education for the improvement of human capital } \\
\text { 3. For studies that have conference references, thesis results, theses, } \\
\text { dissertations and journals, only the ISSN indexed version of the } \\
\text { journal will be included. } \\
\text { 4. For duplicate publications from the same study, only the most } \\
\text { complete and most recent will be included }\end{array}$ \\
\hline Exclusion & 1. Study without strong validation \\
\hline Criteria & $\begin{array}{l}\text { 2. A study that only discusses the development of health and education } \\
\text { for the improvement of human capital } \\
\text { 3. The study is not written apart from Indonesian and English }\end{array}$ \\
\hline
\end{tabular}

The Mendeley software package (http://mendeley.com) is used to store and manage search results. The detailed search process and the number of studies identified at each stage are shown in Figure 3. As shown in Figure 3, the study selection process (Step 5) was carried out in two steps: the exclusion of the primary study by title and the abstract and the exclusion of the main study based on the full text. Literature review studies and other studies that did not include experimental results were excluded. The degree of similarity between the study and the increase in human capital is also included in the study. 


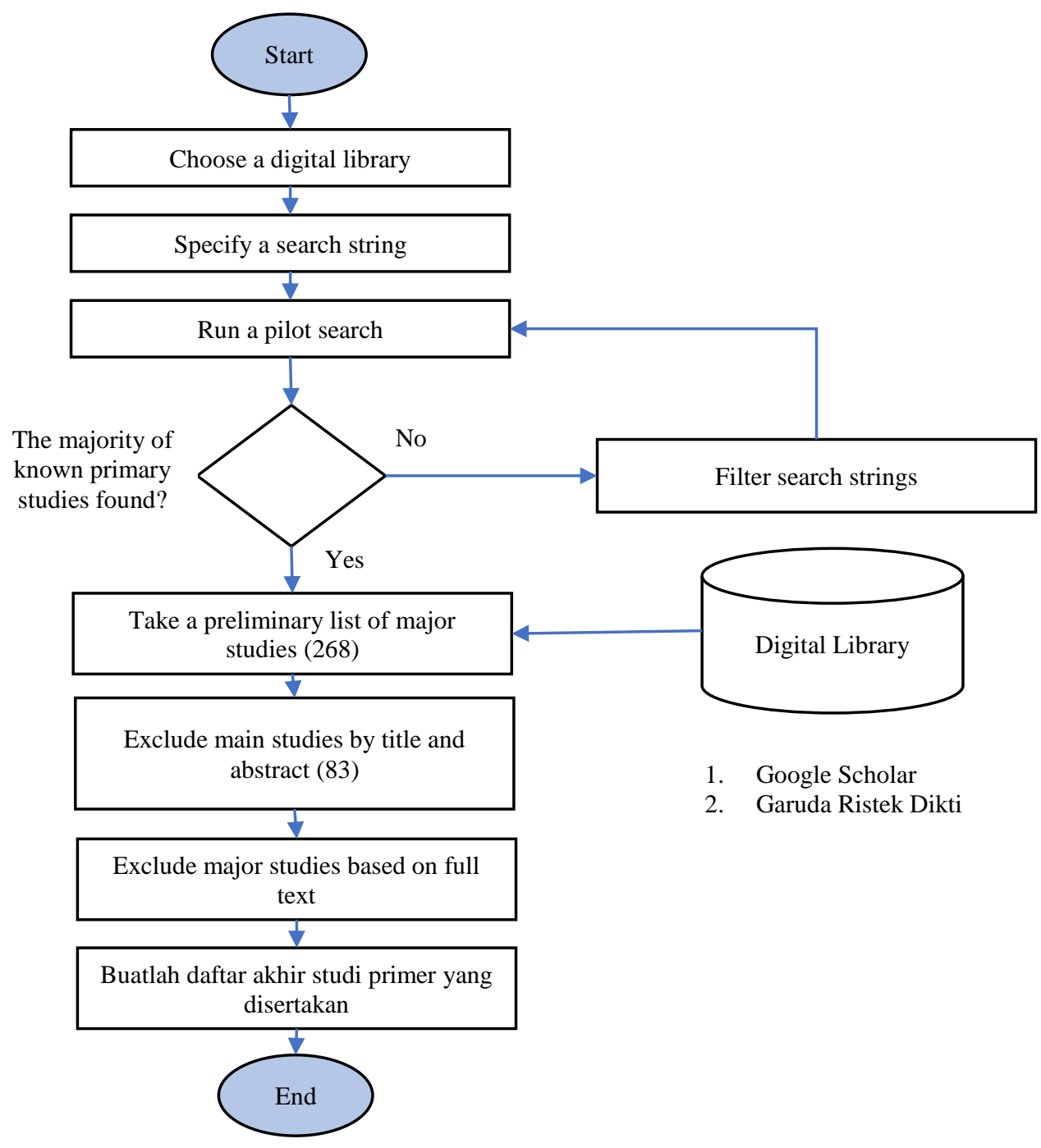

Figure 3. Search and Selection of Primary Studies

The final list of primary studies selected for the first phase has 83 primary studies. Then, the full texts of 83 primary studies were analyzed. Apart from the inclusion and exclusion criteria, the quality of the main study, its relevance to the research question and study similarity were also considered. Similar studies by the same author in multiple journals have been deleted. 83 major studies remained after the exclusion of studies based on full-text selection.

\section{Data Extraction}

The selected main study is extracted and then collected data which contributes to answering the questions related to this research. The data extraction form is designed to collect data from the main study needed to answer the research questions. Properties are identified through the research questions and analysis the researcher conducts. The four 
properties used to answer the research questions are shown in Table 4. Data extraction was carried out iteratively.

Table 4. Data Extraction Properties Mapped to Research Questions

\begin{tabular}{ll}
\hline Property & Research Question \\
\hline Identification and Publication & RQ1, RQ2 \\
\hline Trends and Research Topics & RQ3 \\
\hline $\begin{array}{l}\text { Health and education development methods to increase human } \\
\text { capital }\end{array}$ & RQ4, RQ5, RQ6 \\
\hline $\begin{array}{l}\text { Health and education development framework for enhancing human } \\
\text { capital }\end{array}$ & RQ7 \\
\hline
\end{tabular}

\section{Study Quality Assessment and Data Synthesis}

Assessment of study quality can be used to guide the interpretation of synthesis findings and to determine the strength of the conclusions outlined. The purpose of data synthesis is to gather evidence from selected studies to answer research questions. A piece of evidence may have little proof strength, but the aggregation of many of them can make the point even stronger. The data extracted in this review includes both quantitative data and qualitative data. Various strategies were used to synthesize the extracted data relating to different types of research questions. In general, the narrative synthesis method is used. The data are tabulated in a manner consistent with the questions. Several visualization tools, including bar charts, pie charts, and tables are also used to improve the presentation of the distribution of the prediction method for human capital increase weaknesses.

Threats to Validity

This review aims to analyze studies on human resource improvement based on statistical techniques. This study did not find any bias in selecting studies. The search was not based on the manual reading of all the titles of papers published in the journal. This means that this review may have excluded some human capital improvement papers from some conference proceedings or journals.

\section{RESEARCH RESULTS}

\section{Significant Journal Publications}

In this Systematic Literature Review (SLR), 83 journals analyze the performance of improving human capital. Every year some journals discuss increasing human capital in Indonesia, even most in 2019 several journals with qualitative and quantitative approaches discuss increasing human capital in Indonesia. Figure 4 also shows that the field of research on improving human capital is still very relevant today. 


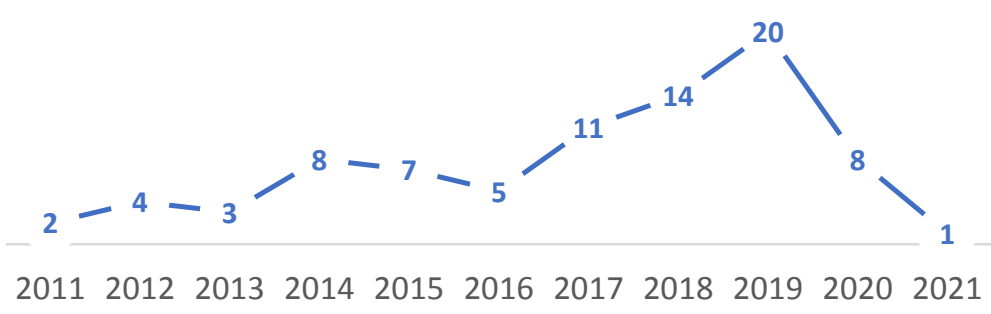

Figure 4. Distribution of Selected Studies over 10 Years

According to the selected primary studies, the most important human capital improvement journals are shown in Figure 5.

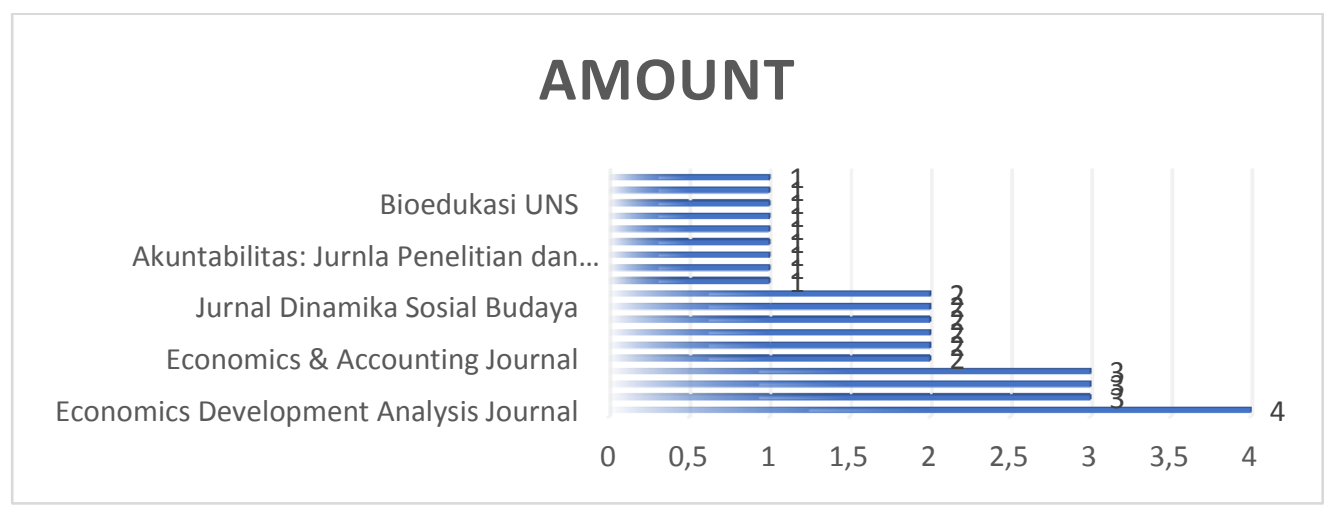

Figure 5. Journal of Publication and Distribution of Selected Studies

\section{Most Active and Influential Researchers}

From the selected primary studies, researchers who contribute very well and are very active in the field of human resource research in Islamic banking in Indonesia can be identified. Figure 6 shows the most active and influential researchers in the field of human capital improvement. Researchers sorted according to the number of studies included in the primary study. It should be noted that Hendarmin, Lina Marlina, Adnan Rajak, Khoirunnisa Azzahra, Evi Andriani, M. Farid Wajdi, Nenny Hendayany, Obilor, Ratna Ekawati, Yuni Kasmawati are active researchers in improving human capital.

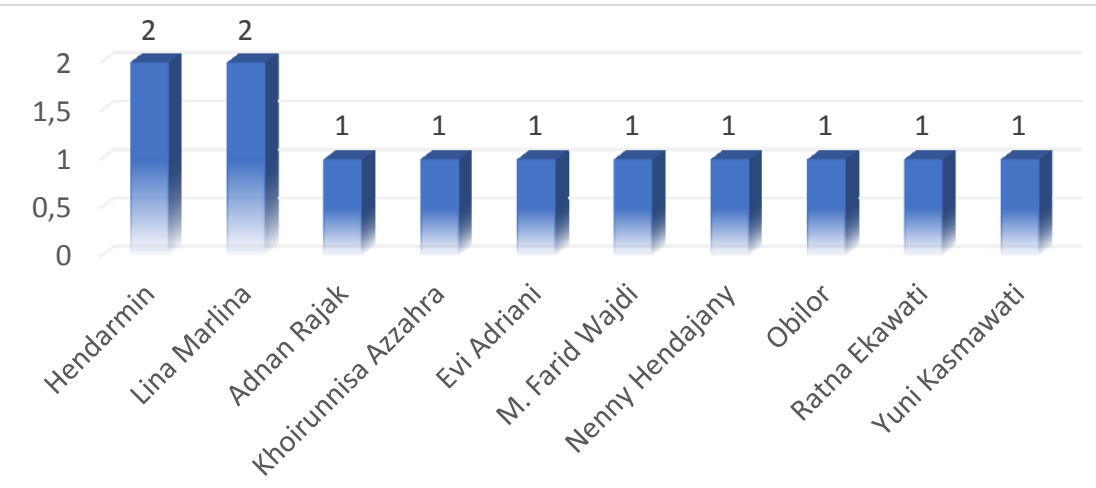

Figure 6. Researchers and the number of works 


\section{Research Topics}

Research on health and education development to improve human capital is the most significant research topic in the field of human capital, in detail in table 5. The analysis of the selected primary studies reveals that research on health and education development for human capital improvement focuses on 5 topics, namely:

1. Identifying problems in health and education development to increase human capital.

2. Looking for the most problems faced in increasing human capital.

3. Find the causes of problems in increasing human capital.

4. Choosing solutions to answers to problems in health and education development to increase human capital.

5. Make conclusions, the most complete and best answer solutions from all research on health and education development for human capital improvement.

The first topic is identifying problems that are focused on health and education development to increase human capital. (Ojo et al. (2019), Suhendra (2020), Anwar (2018), Nizar and Nazir (2020) focus more on discussing improving education and health development for human capital. Munajat and Achmad (2019), Nurjanah (2014), and Esezi (2012) focus more on the role of government policies to improve education for better human capital.

The second topic discussion about the most problems faced in improving human capital is about the low education of human resources which is discussed by several studies, namely Hendajany et al., (2016), Yanti et al., (2020), and (Fahmi \& Mulyono, 2016). Another problem is the slow development in the health sector studied by Prasetyo et al., (2019), Jeneo (2013), and Sokolskaya et al., (2019).

The third topic finds the causes of problems in increasing human capital in health and education is the government's lack of attention in improving education as researched by Tobing (2011) and (Sani et al., 2018). On the other hand, health problems also require the role of the government to increase human capital as studied by Sokolskaya et al., (2019) and Jeneo (2013).

The fourth topic is choosing solutions to answers to problems in increasing human capital. Anwar (2018) said that the determinants of the convergence of human capital in the first period were economic growth, poverty, illiteracy, access to sanitation, access to clean water, the number of health centres, and the number of universities. Farhanah \& Azizah (2013) said that education is needed to optimize the absorption of Indonesian workers 
through character building, entrepreneurial development, and the provision of a nationally integrated online network. From a health perspective, Artana (2016) said that the health of human capital is influenced in addition to genetics, health service facilities and infrastructure, the environment, and is also strongly influenced by the behaviour or culture of human capital itself, as well as the culture of the group where human capital is located. The Tri Hita Karana (THK) culture can improve the character of human capital by increasing its health value.

The fifth topic, namely the most complete and best answer solution from all research on health and education development problems for improving human capital is by improving the quality of education and improving public health facilities to achieve better human capital. (Hendarmin \& Kartika, 2019). To achieve this goal, the government plays an important role in this increase as revealed by Nurjanah (2014) and Suprayitno et al., (2017).

From several journals reviewed, Figure 7 shows the distribution of the total research topics on human capital improvement. $77 \%$ study about education for human capital, 5\% study about health for improvement of human capital and $18 \%$ about education and health for improvement of human capital. It can be concluded that most of the researchers discussed educational development as their research topic. There are several reasons why researchers choose education as their research topic, namely, education is the most important investment in human capital to answer global challenges at this time. Education is defined as an investment in the future because education itself is a tool to develop the economy and not just grow the economy. In modern educational management praxis, one of the five functions of education is a technical-economic function from the individual level to a broader level.

The role of education as human capital is as a forum or tool to prepare a skilled workforce because education is one aspect that supports and can contribute to economic development. Therefore, education is highly emphasized to improve the quality and quality of human resources.

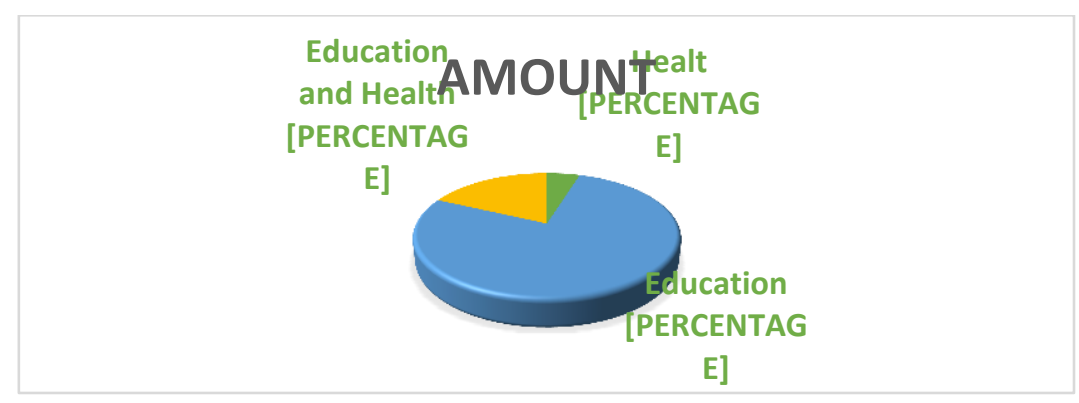

Figure 7. Distribution of Research Topics 


\section{Research methods}

Almost all researchers used a quantitative approach with a total of 51 studies. In addition to the quantitative approach, the qualitative approach is also widely used by researchers either with library research, observation, in-depth interviews, or phenomenology and only a few studies use a mixed-method, namely Maridi (2011) and Putri (2017).

The percentage of using research methods is in Figure 8. below. The best method that should be used to research the development of health and education for the improvement of human capital is a combination of qualitative and quantitative methods. Why is that? Because with this method the existing problems that will be answered in a study can be explained by various approaches using qualitative methods as well as can be proven statistically mathematically using quantitative methods, to obtain a complete analysis result. Quantitative methods are used to obtain measurable analysis results regarding the picture of health and education development to increase human capital, and qualitative methods are used to obtain information about efforts to increase human capital.

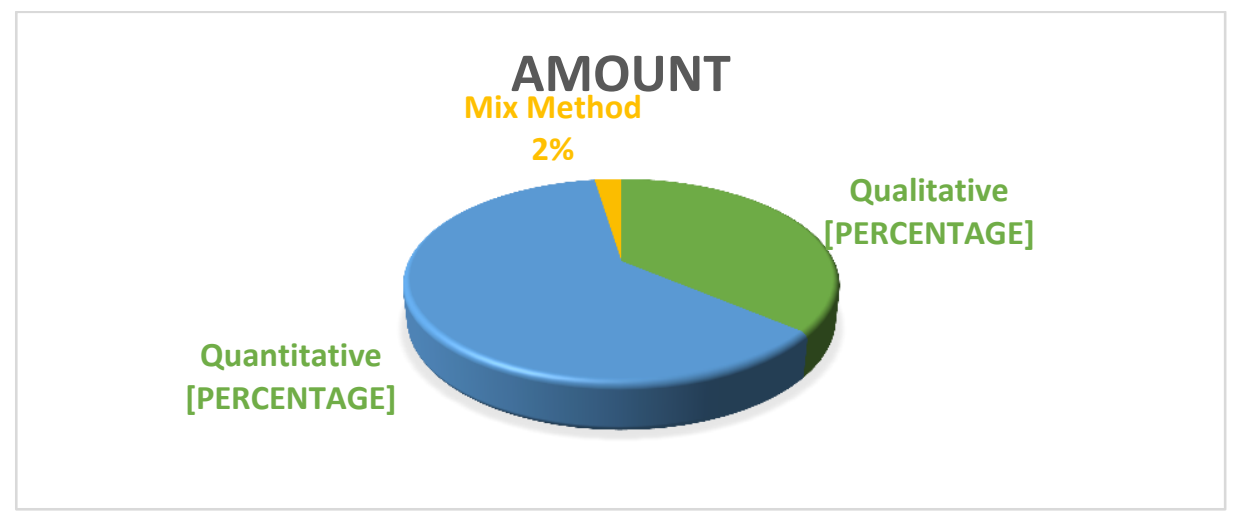

Figure 8. Percentage of methods used by researchers

Nurrachmi (2020) conduct a qualitative approach based on observation, online research, analysis of studies from journals and brainstorming with other researchers from 2016 to 2019 to explain the theory of educational attainment is not based on the fact that there are cases in developing countries where highly educated workers are paid less, which contrasts with the theory that education will affect society's higher wages.

In terms of health, Artana (2016) also takes a qualitative approach answering that health defined by the World Health Organization (WHO), which was originally meant to be healthy only physically, psychologically, socially, and free from disabilities, has now been added to being spiritually healthy. Human capital health is influenced in addition to genetics, health service facilities and infrastructure, the environment, and is also strongly influenced by the behaviour or culture of human capital itself, as well as the culture of the 
group where human capital is located. The Tri Hita Karana (THK) culture can improve the character of human capital by increasing its health value.

\section{CONCLUSION}

The results of the Systematic Literature Review from all research contained in journals that have been published from 2011 to 2021 state that human capital is still low, both in terms of education and from a health perspective, from a theoretical and practical standpoint it has not been able to balance the development of human capital. The low level of education and health causes weak human capital.

Based on the designed inclusion and exclusion criteria, 83 studies were identified. This literature review is conducted as a Systematic Literature Review. Systematic Literature Review is defined as the process of identifying, assessing, and interpreting all available research evidence to provide answers to specific research questions.

The analysis of the selected primary studies reveals that human capital research currently focuses on two topics and trends: education and health development. The method often used in human capital research is a quantitative approach of $62 \%$, a qualitative approach of $36 \%$ and a mixed-method approach of $2 \%$.

The cause of the low increase in human capital is the government's lack of attention in improving education and health. The solution given to answer the problem of low human capital is by improving the quality of education and improving public health facilities to achieve better human capital. To achieve this goal, the government plays an important role in this increase.

\section{REFERENCES}

Adriani, E. (2019). Pengukuran Modal Manusia (Suatu Studi Literatur). J-MAS (Jurnal Manajemen Dan Sains), 4(1), 176. https://doi.org/10.33087/jmas.v4i1.86

Anwar, A. (2018). Empirical Analysis of Human Capital Convergence in Indonesia. JEJAK: Jurnal Ekonomi Dan Kebijakan, 11(2), 306-322. https://doi.org/10.15294/jejak.v11i2.16053

Artana, I. (2016). Tri Hita Karana Meningkatkan Kualitas Modal Manusia Dari Persfektif Kesehatan. Piramida, 10(2), 100-105.

Esezi, I. (2012). Human Capital Development: Efforts at Enhancing the Teaching and Learning of Science and Mathematics in Nigeria. Mediterranean Journal of Social Sciences, 3(15), 42-49. https://doi.org/10.5901/mjss.2012.v3n15p42 
Fahmi, M., \& Mulyono, Y. O. (2016). Pendidikan, Human Capital ataukah Signaling? Studi Kasus Indonesia. Jurnal Ekonomi Dan Pembangunan Indonesia, 15(2), 113. https://doi.org/10.21002/jepi.v15i2.560

Farhanah, L., \& Azizah, R. (2013). Optimalisasi Penyerapan Tenaga Kerja Indonesia Melalui Pengembangan Human Capital Dan Penyediaan Jaringan Kerja Online Yang Terintegrasi Secara Nasional. Economics Development Analysis Journal, 2(2), 140146. https://doi.org/10.15294/edaj.v2i2.1403

Hendajany, N., Widodo, T., \& Sulistyaningrum, E. (2016). HUMAN CAPITAL VERSUS THE SIGNALING HYPOTHESES: THE CASE OF INDONESIA Faculty of Economics, Universitas Sangga Buana YPKP Bandung Faculty of Economics and Business, Universitas Gadjah Mada Faculty of Economics and Business, Universitas Gadjah Mada. Journal of Indonesian Economy and Business, 31(2), 192-207.

Hendarmin, H., \& Kartika, M. (2019). The Relationship Between Human Capital and the Regional Economy Productivity. JEJAK: Jurnal Ekonomi Dan Kebijakan, 12(1), 138152. https://doi.org/10.15294/jejak.v12i1.18396

Jeneo, A. (2013). PENGARUH HUMAN CAPITAL, STRUCTURE CAPITAL, DAN PHYSICAL CAPITAL TERHADAP KINERJA PERUSAHAAN PERBANKAN DI INDONESIA. TEKUN: Jurnal Telaah Akuntansi Dan Bisnis, 4(4), 247-263.

Jojo, J., Gandhy, A., Simanullang, E. S., \& Frasipa, A. (2019). Analisis Human Capital Terhadap Pertumbuhan Ekonomi Indonesia Periode 2001 - 2017. Optima, 3(1). https://doi.org/10.33366/optima.v3i1.1250

Kitchenham, B., \& Charters, S. (2007). Guidelines for performing systematic literature reviews in software engineering.

Kumar, C. S. (2006). Human capital and growth empirics. The Journal of Developing Areas, $153-179$.

Maridi, M. (2011). Modal Manusia Untuk Konservasi Waduk Wonogiri (Studi Kasus Di Sub Daerah Aliran Sungai Keduang). Bioedukasi UNS, 4(2), 86-94. https://doi.org/10.20961/bioedukasi-uns.v4i2.2640

Munajat, N., \& Achmad, A. A. (2019). Human Capital and Policies on Professional Development of Islamic Education Teachers at the Department of Ministry Religion Affair Yogyakarta. Jurnal Pendidikan Islam, 7(2), 405-418. https://doi.org/10.14421/jpi.2018.72.405-418

Nizar, N. I., \& Nazir, A. (2020). Faktor Human Capital Pada Pertumbuhan Ekonomi Kreatif. Jurnal Mandiri: Ilmu Pengetahuan, Seni, Dan Teknologi, 4(1), 52-65. https://doi.org/10.33753/mandiri.v4i1.103

NURJANAH, S. (2014). Human Capital Dan Peranan Pemerintah Dalam Pendidikan. Econosains Jurnal Online Ekonomi Dan Pendidikan, 12(1), 83-90. https://doi.org/10.21009/econosains.0121.04

Nurrachmi, R. (2020). A Survey Study of Human Capital and Educational Attainment. 
Airlangga International Journal of Islamic Economics and Finance, 2(2), 85. https://doi.org/10.20473/aijief.v2i2.20645

Prasetyo, W. B., Yanuar, T., Syah, R., Pusaka, S., \& Ramdhani, D. (2019). Human Capital for Start-up Business Implementation over Home Care " 4 Care " Application Programs. Journal of Multidisciplinary Academic, 3(5), 189-192.

Putri, A. K. (2017). Determinants Identification of Poverty and Human Capital of Fisherman Household. Integrated Journal of Business and Economics, 1(2), 43-51. https://doi.org/https://doi.org/10.5281/zenodo.1153808

Radjenović, D., Heričko, M., Torkar, R., \& Živkovič, A. (2013). Software fault prediction metrics: A systematic literature review. Information and Software Technology, 55(8), $1397-1418$.

Sani, R. M., Sambodo, H., \& Bambang, B. (2018). The Effect of Human Capital, Labors, and Capital on Economic Growth in Barlingmascakeb. Eko-Regional Jurnal Pengembangan Ekonomi Wilayah, 13(2), 60-68. https://doi.org/10.20884/1.erjpe.2018.13.2.1172

Sokolskaya, M. V., Madzhuga, A. G., Babieva, N. S., Khvostunov, K. ., Moskvina, A. V., Abdullina, L. B., Kanbekova, R. V., Salimova, R. M., \& Golovneva, E. V. (2019). The effect of personal health on the formation of human capital: a metasystem approach. International Journal of Public Health Science (IJPHS), 8(1), 135. https://doi.org/10.11591/ijphs.v8i1.17837

Suhendra, I. (2020). Determinan Modal Manusia Di Indonesia: Menggunakan Estimasi Panel Pendahuluan. Jurnal Riset Bisnis Dan Manajemen Tirtayasa, 4(2), 162-177.

Suprayitno, B., Nurseto, T., \& Supriyanto, S. (2017). Produktifkah Human Capital Investment Oleh Pemerintah Daerah Provinsi Dalam Era Desentralisasi? Jurnal Economia, 13(1), 39. https://doi.org/10.21831/economia.v13i1.11154

Tobing, C. R. E. (2011). The Significant Contribution of Indonesian Human Capital to the Economic Growth. International Research Journal of Business Studies, 4(1), 49-57. https://doi.org/10.21632/irjbs.4.1.49-57

Todaro, M. P., \& Smith, S. C. (2006). Pembangunan ekonomi.

Unterkalmsteiner, M., Gorschek, T., Islam, A. K. M. M., Cheng, C. K., Permadi, R. B., \& Feldt, R. (2011). Evaluation and measurement of software process improvement - a systematic literature review. IEEE Transactions on Software Engineering, 38(2), 398424.

Yanti, N., Nurtati, N., \& Misharni, M. (2020). INVESTASI MODAL MANUSIA BIDANG PENDIDIKAN: DAMPAK PENGANGGURAN DAN PERTUMBUHAN EKONOMI. Jurnal Ekonomi Pembangunan ... http://www.journal.stiem.ac.id/index.php/jurep/article/view/504 